\title{
Antisipasi Pencegahan Bullying Sedini Mungkin: Program Anti Bullying Terintegrasi untuk Anak Usia Dini
}

\author{
Ririn Ambarini, Eva Ardiana Indrariani, Ayu Dian Zahraini \\ Universitas PGRI Semarang \\ ririnambarini@upgris.ac.id
}

Key word:

Learning, RPP, Lesson Plan, Anti-bullying, School Based

Kata Kunci

Pembelajaran, RPP, Anti bullying, Berbasis Sekolah

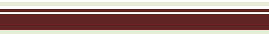

\section{Abstract}

The main purpose of this service is that teachers and PAUD staff can implement and implement anti-bullying programs as prevention and also anticipation in their respective schools so that teachers and PAUD staff can assist young children to develop social skills so they can interact positively and develop any efforts which can effectively help prevent and stop the emergence of intimidation in early childhood life. Implementation of Community Service is done in the form of training activities, and field assistance which is divided into four stages in a systematic and sustainable way. The methods used in the implementation of this program include training, lectures, frequently asked questions, and discussions, teaching practices and worksheets that are the participants' outputs from this training. In implementation role playing stage, teachers who are less experienced and still new, are still asking for enlightenment and examples of solutions from senior teachers and the dedication team. The result of this community services are the satisfaction of the partner, the commitment of the teachers at PAUD to prepare the RPP about bullying, and most of them use story telling and role playing to internalize the anti bullying program.

\section{Abstrak}

Tujuan utama adalah guru dan staf PAUD dapat melaksanakan dan menerapkan program-program anti bullying sebagai pencegahan dan antisipasi di sekolah masing masing sehingga guru dan staf PAUD dapat membantuk anak usia dini untuk mengembangkan ketrampilan sosial dan dapat berinteraksi secara positif dan mengembangkan berbagai usaha yang secara efektif dapat membantu mencegah dan menghentikan munculnya bullying dalam kehidupan anak usia dini. Pelaksanaan kegiatan dilakukan dalam bentuk kegiatan pelatihan, dan pendampingan lapangan yang terbagi dalam empat tahapan secara sistematis dan berkesinambungan. Metode yang digunakan dalam pelaksanaan program ini meliputi pelatihan, ceramah, tanya jawab, dan diskusi, praktek mengajar serta lembar kerja yang merupakan output peserta dari pelatihan ini. Pada tahap implementasi, hal menarik yang ditemukan adalah guru yang masih baru yang belum memiliki pengalaman yang matang masih sering bertanya kepada guru senior dan tim pengabdi. Hasil dari kegiatan ini adalah kepuasan mitra, komitmen para guru di PAUD untuk menyiapkan RPP tentang bullying, dan menggunakan story telling dan bermain peran untuk anti bullying. 


\section{PENDAHULUAN}

Bullying bisa muncul pada masa kanakkanak atau usia dini. Anak yang berusia 3 tahun dapat dan sekaligus bisa berpartisipasi dalam tindakan bullying. Para guru PAUD seringkali tidak memperhatikan bullying karena beberapa alasan. Banyak para guru PAUD yang berpikir bahwa anak-anak itu terlalu naif dan juga terlalu bersih untuk melakukan tindakan bullying dan mereka dianggap tidak mampu untuk melakukan tindakantindakan yang dapat melukai atau mengganggu anak yang lain. Para guru tidak menyadari bahwa penyebab dari bullying itu sendiri adalah karena kurangnya pengawasan atau bahkan hal tersebut terjadi ketika orang dewasa tidak melihat kejadian tersebut. Penyebab lainnya adalah kegagalan para guru PAUD untuk memahami bahwa perilaku awal atau pre-bullying akan bisa berubah menjadi bullying (Ahmed \& Braithwaite, 2006).

Jika bullying pada usia dini dianggap sebelah mata atau tidak dihentikan, anak-anak yang melakukan tindakan bullying akan terus melakukan tindakan bullying sampai mereka tumbuh remaja, dan anak-anak yang menjadi korbannya akan tetap menderita secara berkelanjutan. Pada dasarnya, perilaku bullying akan semakin menyebar ketika anak-anak yang lain juga melihat kesempatan-kesempatan untuk terlibat dalam perilaku bullying. Jika dibiarkan berlanjut, pola-pola bullying dan efek-efek yand diderita oleh korban-korban bullying akan terbawa sampai masa remaja mereka dan bahkan masa dewasa, dan hasilnya adalah adanya hubungan antara remaja yang kasar dan ada unsur-unsur penghinaan, hingga pada akhirnya adanya kekerasan dalam rumah tangga atau bahkan tindakan-tindakan kriminal (Bollmer, Harris, \& Milich, 2006).

Banyak perundangan yang bisa dijadikan sandaran hukum pentingnya melakukan program anti-bullying, diantaranya adalah pasal-pasal yang ada dalam kitab Undang-undang Hukum Pidana maupun UUPA (Undang-Undang Perlindungan Anak). Menurut pasal 77 UUPA:

Setiap orang yang dengan sengaja melakukan tindakan :

a. diskriminasi terhadap anak yang mengakibatkan anak mengalami kerugian, baik materiil maupun moril sehingga menghambat fungsi sosialnya; atau

b. penelantaran terhadap anak yang mengakibatkan anak mengalami sakit atau penderitaan, baik fisik, mental, maupun sosial, dipidana dengan pidana penjara paling lama 5 (lima) tahun dan/atau denda paling banyak 


\section{Rp 100.000.000,00 (seratus juta rupiah).}

Menurut pasal 54 UU No. 23 Tahun 2002 tentang Perlindungan Anak menegaskan: "Anak di dalam dan dilingkungan sekolah wajib dilindungi dari tindakan kekerasan yang dilakukan oleh guru, pengelola sekolah atau temantemannya di dalam sekolah yang bersangkutan atau lembaga pendidikan lainnya.

Hasil konsultasi Komisi Nasional Perlindungan Anak dengan anak-anak di 18 provinsi di Indonesia pada tahun 2007 memperlihatkan bahwa sekolah juga bisa menjadi tempat yang cukup berbahaya bagi anak-anak, jika ragam kekerasan di situ tidak diantisipasi (MG. Endang Sumiarni, 2009). Kasus kekerasan terhadap anakanak di sekolah menduduki peringkat kedua setelah kekerasan pada anak-anak dalam keluarga. Padahal, jika siswa kerap menjadi korban kekerasan, mereka dapat memiliki watak kekerasan di masa depan. Hal ini secara kolektif akan berdampak buruk terhadap kehidupan bangsa (Jolliffe \& Farrington, 2006).

Berdasarkan kenyataan tersebut di atas, kekerasan (bullying) seolah-olah sudah menjadi bagian yang tak terpisahkan dari kehidupan anak-anak di zaman yang penuh dengan persaingan ini. Kiranya, perlu dipikirkan mengenai resiko yang dihadapi anak, dan selanjutnya dapat dicarikan jalan keluar untuk memutus rantai kekerasan yang saling berkelitberkelindan tanpa habis-habisnya. Tentunya, berbagai pihak bertanggung jawab atas kelangsungan hidup anak, karena anak-anak juga memiliki hak yang harus dipenuhi oleh negara, orang tua, guru, dan masyarakat. Diperlukan komitmen bersama dan langkah nyata untuk mecegah kekerasan (bullying) di sekolah (Efianingrum, 2009).

Guru PAUD dapat membantu anak untuk mengembangkan ketrampilanketrampilan sosial untuk berinteraksi secara positif dan mengembangkan berbagai usaha yang melawan aksi bullying. Untuk secara efektif membantu mencegah dan menghentikan munculnya intimidasi dalam kehidupan anak usia dini, ada hal-hal tertentu yang pendidik perlu memahami dan siap untuk melakukan. Program anti bullying di desain untuk membantu pendidik di PAUD untuk memahami bullying, mempelajari apa yang bisa dilakukan untuk mencegah bullying, mengembangkan kegiatan-kegiatan yang dapat membangun kemampuan sosial anak, dan mengembangkan rencana tindakan intervensi (Nansel, Overpeck, Pilla, Ruan, Simons-Morton, \& Scheidt, 2001)

Perilaku bullying tidaklah muncul secara tiba-tiba dan misterius diantara 
anak-anak. Para pendidik di PAUD sebaiknya menyadari dan mengawasi anakanak yang terlibat dalam perilaku bullying. Munculnya bullying didasarkan pada pembentukan hubungan tertentu antara anak-anak yang menggertak, anak-anak yang diganggu, dan anak-anak yang mengamati bullying-pengganggu, korban, dan penonton (Olweus, Limber, \& Mihalic, 1999).

Pendidikan anak usia dini adalah tempat dimana anak-anak pertama kali mengamati dan mengalami bentuk-bentuk awal dari perilaku bullying. Jika pendidik di PAUD tidak melakukan intervensi untuk menghentikan perilaku bullying, anak-anak akan belajar bahwa bullying adalah suatu cara yang dapat diterima untuk berperilaku. Kunci kesuksesan dari program antibullying adalah persiapan sebelumnya untuk menangani bullying secara efektif sebelum, selama, dan sesudah perilaku tersebut terjadi (Orpinas \& Horne, 2005).

Berbicara langsung dan terbuka tentang bullying dengan anak-anak akan memberikan kesempatan bagi anak memahami bahwa orang dewasa yang mempedulikan mereka menangani bullying secara serius dan memastikan bahwa bullying tidak akan terjadi di kelas PAUD mereka. Memastikan bahwa anak-anak mengetahui bahwa jika suatu perilaku bukanlah bullying, maka perilaku seperti melukai orang lain dengan menggunakan kata-kata, tindakan, atau pengucilan hubungan adalah tidak dibenarkan dan perlu dihentikan (Vaillancourt, Hymel, \& McDougall, 2003).

Pendidik anak usia dini dapat mengajar, memberikan model, dan mempersiapkan anak-anak untuk mempraktekkan keterampilan yang mereka butuhkan untuk mengembangkan persahabatan dan membantu menghentikan dan mencegah bullying. Selain itu, pendidik anak usia dini juga dapat mengajarkan anak-anak bagaimana menahan diri saat teman lain mengintimidasi atau mem-bully dengan membantu mereka belajar dan berlatih empati saat berhubungan langsung dengan situasi intimidasi atau bullying.

Guru PAUD dapat memberikan pengetahuan kepada siswa bagaimana belajar keterampilan ketegasan yang melibatkan belajar bagaimana mengekspresikan perasaan diri sendiri dan membela hak-hak sendiri dengan cara-cara yang juga menghormati perasaan dan hakhak orang lain (Sharp \& Smith, 1994).

Jika anak-anak tidak merasa aman, mereka harus selalu mencari bantuan dari orang dewasa. Para pendidik PAUD harus dapat memberikan penjelasan beserta ilustrasi contoh tentang perbedaan antara mengadu dan melaporkan. Dalam hal ini 
mengadu adalah memberikan informasi tentang seorang anak kepada guru bukan karena ada seorang anak yang sedang dalam keadaan tersakiti ataupun karena ada seorang anak melanggar peraturan akan tetapi hanya berdasarkan perasaan tidak suka. Sedangkan melaporkan adalah karena ada suatu peristiwa dimana seorang anak dalam keadaan bahaya dikarenakan ada anak yang lain yang melanggar peraturan (Phillips, 2007).

Para pendidik PAUD perlu untuk mengingatkan kepada anak-anak tentang perbedaan antara intimidasi (melibatkan ketidakseimbangan kekuatan) dan konflik (melibatkan ketidaksepakatan antara anakanak dari kekuasaan yang sama). Jelaskan bahwa tidak pernah salah untuk meminta bantuan orang dewasa dalam situasi yang melibatkan bullying. Menciptakan lingkungan yang bebas dari intimidasi atau bullying dalam dunia anak usia dini membutuhkan orang-orang dewasa dan anak-anak-untuk memahami bahwa bullying tidak dapat diterima, menyakitkan, dan dapat dicegah dan perlu mengambil tanggung jawab untuk menghentikan itu (Taub, 2001).

Anak-anak perlu tahu bahwa sekolah PAUD mereka memiliki aturan dan harapan tentang antisipasi terhadap intimidasi atau bullying yang membantu semua anak merasa aman, tidak dikucilkan, dan mendapat dukungan saat mereka mengembangkan bakat dan minat mereka belajar di sekolah. Dalam hal ini, anakanak membutuhkan bantuan mengembangkan keyakinan yang dapat mempersiapkan mereka untuk mencegah daripada mempromosikan bullying. Dalam hal ini guru dapat memanfaatkan momen pembelajaran untuk membantu anak-anak belajar bagaimana mencegah dan menghentikan bullying. Selanjutnya, penting bagi guru untuk selalu mengamati tindakan anak-anak, kata-kata, bahasa tubuh, dan ekspresi wajah akan membantu menentukan apakah intimidasi atau bullying sedang terjadi (Rios-Ellis, Bellamy, \& Shoji, 2000).

Banyak perundangan yang bisa dijadikan sandaran hukum pentingnya melakukan program anti-bullying, diantaranya adalah pasal-pasal yang ada dalam kitab Undang-undang Hukum Pidana maupun UUPA (Undang-Undang Perlindungan Anak). Menurut pasal 77 UUPA: Setiap orang yang dengan sengaja melakukan tindakan diskriminasi terhadap anak yang mengakibatkan anak mengalami kerugian, baik materiil maupun moril; atau penelantaran terhadap anak yang mengakibatkan anak mengalami sakit atau penderitaan, baik fisik, mental, maupun sosial, dipidana dengan pidana penjara paling lama 5 (lima) tahun dan/atau denda 
paling banyak Rp 100.000.000,00 (seratus juta rupiah).

Sedangkan menurut pasal $54 \mathrm{UU}$ No. 23 Tahun 2002 tentang Perlindungan Anak menegaskan: " Anak di dalam dan dilingkungan sekolah wajib dilindungi dari tindakan kekerasan yang dilakukan oleh guru, pengelola sekolah atau temantemannya di dalam sekolah yang bersangkutan atau lembaga pendidikan lainnya.

Untuk dapat mengimplementasikan pembelajaran di sekolah yang ramah anak dimana anak merasa bahagia dan aman selama di, ke, dan dari sekolah perlu pelatihan dan pengembangan pembelajaran anti-bullying berbasis sekolah bagi guru PAUD kota Semarang.

Tetapi pada kenyataannya, masih banyak sekolah PAUD yang belum menerapkan program anti-bullying secara khusus dan juga efektif. Sebagian besar guru dan staff, ataupun pejabat struktural di PAUD belum menerapkan program khusus untuk mengatasi ataupun mengantisipasi bullying di Sekolah.

Permasalahan yang dihadapi oleh mitra PAUD Nurul Ilmi Semarang dan PAUD Doa Ibu Semarang adalah:

1. Tngkat, keseriusan, dan dinamika dari bullying masih sangat kurang.

2. Pengenalan dan bagaimana memberikan tanggapan se-awal dan seefektif mungkin terhadap perilaku yang dapat menyebabkan bullying masih belom maksimal.

3. Pengembangan strategi-strategi baru dan efektif tentang bagaimana mencegah bullying masih perlu di tingkatkan dan di update.

4. Kegiatan terkait dengan persiapan anak didik agar mampu mengenali dan merespon secara efektif perilaku awal dari bullying masih kurang.

5. Kegiatan pembelajaran terkait dengan mempersiapkan anaksupaya dapat membantu mencegah dan menghentikan bullying masih belum dimaksimalkan.

6. Penciptaan suatu lingkungan dimana setiap orang dapat memahami bahwa perilaku-perilaku bullying tidak dapat diterima, merusak, akan tetapi juga dapat dicegah masih belum terjadwal atau tersistem dengan baik.

7. Pemberdayaan diri sendiri (guru dan staff PAUD) dan anak-anak untuk secara aktif memberikan intervensi untuk mencegah dan menghentikan bullying belum memuaskan dan belum terjadwal secara sistematis.

8. Antisipasi dan intervensi dampak bullying dari segi kesehatan anak 
belum dilaksanakan secara maksimal.

9. Pembelajaran dan penyusunan RPP tentang bullying yang bisa diterapkan selama proses belajar mengajar selama kurang lebih 30 menit, minimal sekali dalam seminggu dengan menggunakan materi poster, puppet role-play, story times, dan classroom rules belum diterapkan secar eksplisit. Berkaitan dengan hal tersebut diatas, maka dipandang perlu adanya penataran, pelatihan, pembimbingan dan pendampingan tentang program antibullying berbasis sekolah. Oleh karena itu, diperlukan adanya forum untuk memfasilitasi kegiatan tersebut bagi guru, khususnya guru PAUD di kota Semarang.

Target kegiatan ini adalah guru dan staf di TK Mekar Jaya Semarang dan PAUD Doa Ibu Semarang. Pencegahan bullying akan sukses apabila melibatkan pendidikan, persiapan, dan kerja tim. Luaran yang diharapkan dari rogram antibullying untuk mitra TK Mekar Jaya Semarang dan PAUD Doa Ibu Semarang adalah dapat memberikan wacana-wacana khusus, stategi-strategi, kegiatan-kegiatan, serta sumber-sumber yang merujuk pada perilaku bullying penanganan serta pencegahannya dalam bentuk perangkat pembelajaran dan penyuluhan kesehatan dan gizi untuk antisipasi dan intervensi dampak bullying yang mempunyai efek serius pada kesehatan anak usia dini yang dapat diterapkan oleh guru dan staff PAUD di lingkungan sekolah PAUD.

Mitra TK Mekar Jaya mempunyai guru dan staff yang berjumlah 8 orang sedangkan PAUD Doa Ibu mempunyai guru dan staff yang berjumlah 8 orang. Setiap peserta diharapkan berpartisipasi aktif dalam program anti-bullying ini dan dalam pada setiap tahap materi yang disampaikan. Oleh karena itu pendampingan perlu dilakukan yang dimulai dari tahap materi pertama hingga terakhir yaitu pembuatan RPP tentang bullying yang nantinya diharapkan dapat diterapkan selama proses belajar mengajar di lingkungan Sekolah baik di dalam maupun di luar kelas.

\section{METODE PELAKSANAAN}

Pengabdian pada masyarakat Ibm ini akan dilakukan dalam bentuk kegiatan pelatihan, workshop dan pendampingan lapangan yang terbagi dalam 5 (lima) tahapan secara sistematis dan berkesinambungan. Tiap tahapan akan diikuti oleh guru-guru mitra TK Mekar Jaya Semarang dan PAUD Doa Ibu Semarang dengan jumlah peserta 16 guru dan staff. 
Tahapan kegiatan akan berlangsung sebagai berikut:

1. Tahap I (Tahap Penyampaian Materi) Pada tahap ini akan dilakukan penyampaian materi yang meliputi:

a. Tingkat, keseriusan, dan dinamika dari bullying.

b. Bagaimana mengenali dan menanggapi se-awal dan se-efektif mungkin perilaku yang dapat menyebabkan bullying.

c. Strategi-strategi baru dan efektif tentang bagaimana mencegah bullying.

d. Bagaimana mempersiapkan anak-anak agar mengenali dan merespon secara efektif perilaku awal dari bullying.

e. Pengajaran kepada anak-anak bagaimana setiap orang (pembuli, korban bullying, dan saksi bullying, serta orang dewasa yang suportif) dapat membantu mencegah dan menghentikan bullying.

f. Penciptaan suatu lingkungan dimana setiap orang dapat memahami bahwa perilaku-perilaku bullying adalah tidak dapat diterima, merusak, akan tetapi juga dapat dicegah.

g. Pemberdayaan diri sendiri (guru dan staff PAUD) dan anak-anak untuk secara aktif memberikan intervensi untuk mencegah dan menghentikan bullying. h. Antisipasi dan intervensi dampak bullying dari segi kesehatan anak.

i. Teknik penyusunan RPP tentang bullying yang bisa diterapkan selama proses belajar mengajar selama kurang lebih 30 menit, minimal sekali dalam seminggu dengan menggunakan materi poster, puppet role-play, story times, dan classroom rules.

Materi tersebut disampaikan dalam bentuk ceramah, tanya jawab, pelatihan, dan diakhiri dengan penugasan penyusunan RPP tentang bullying serta peer teaching sebagai simulasi dan sekaligus sebagai implementasi dari RPP tentang bullying yang telah di susun. Kegiatan ini akan dilaksanakan di kampus TK Mekar Jaya Semarang dan juga kampus PAUD Doa Ibu Semarang.

\section{Tahap II (Tahap Pelatihan)}

Pada tahap ini, peserta berlatih menyusun RPP tentang bullying sebagai tindak lanjut dari tahap pertama. Diharapkan dalam pelatihan ini, guru dapat menghasilkan RPP tentang bullying yang kemudian untuk implementasi RPP tentang bullying tersebut dapat diterapkan dalam latihan peer teaching.

3. Tahap III ( Tahap Praktik Peer Teaching)

Setiap guru pada tahap ini melakukan praktek pembelajaran bullying dengan rekan mereka sendiri dalam bentuk 
peer teaching. Teknik pembimbingan dan pendampingan dilakukan untuk mengetahui tingkat pemahaman guru terhadap bagaimana penerapan RPP tentang bullying yang diterapkan dalam bentuk pembelajaran tentang bullying yang diintegrasikan dalam proses pengajaran di kelas melalui peer teaching.

4. Tahap IV (Tahap Praktik Classroom Practice)

Setiap guru pada tahap ini adalah kelanjutan dari tahap sebelumnya dimana guru melakukan praktek pembelajaran bullying dengan rekan mereka sendiri di kelas mereka masing-masing. Teknik pembimbingan dan pendampingan dilakukan untuk mengetahui tingkat pemahaman guru terhadap bagaimana penerapan RPP tentang bullying yang diterapkan dalam bentuk pembelajaran tentang bullying yang diintegrasikan dalam proses pengajaran di sekolah mereka sendiri, yakni dalam bentuk:

a) Tim pelaksana pengabdian pada masyarakat melakukan pemantauan dan evaluasi ke sekolah-sekolah tempat praktik guru menerapkan pembelajaran tentang bullying,

b) Melakukan bimbingan dan pendampingan di luar sekolah seperti melalui telepon dan e-mail,

c) Guru dapat melakukan konsultasi dengan tim pelaksana (instruktur) di kampus Universitas PGRI

Semarang jika diperlukan,

5. Tahap V ( Tahap Diskusi \& Refleksi Diri)

Pada tahap ini adalah tahap diskusi dan refleksi diri sekaligus sharing dari masing-masing guru tentang kelebihan dan juga kekurangan terhadap pembelajaran bullying sebagai bagian dari pelatihan dan pengembangan pembelajaran anti-bullying yang diterapkan di sekolah mereka. Bimbingan dan pendampingan pada tahap ini dilakukan di kampus TK Mekar Jaya Semarang dan juga kampus PAUD Doa Ibu Semarang.

\section{PEMBAHASAN}

Program pengabdian masyarakat yang dilakukan oleh tim pengabdi adalah pelatihan dan pengembangan pembelajaran anti-bullying berbasis sekolah bagi guru PAUD di Kota Semarang. Dengan adanya pelatihan ini diharapkan warga sekolah dalam hal ini di lingkungan PAUD akan lebih meningkatkan pengawasan bullying pada anak usia dini karena jika bullying tidak dihentikan maka perilaku bullying akan berkembang dan menyebar. Sangatlah penting berbagi pemaham kepada lingkungan PAUD tentang segala hal yang terkait dengan bullying, termasuk didalamnya adalah segala definisi, gejala, akibat, korban, pelaku bullying. 
Dalam pelatihan ini, ada sesi tanya jawab atau sharing tentang mencari cara menghentikan bullying sebelum hal tersebut dilakukan. Dalam hal ini pendidik anak usia dini perlu memperhatikan perilaku khusus anak anak yang ditengarai adalah bullying.

Anak-anak yang mengatakan, "kamu tidak boleh bermain dengan ku," mungkin tidak punya tendensi khusus dengan mengatakan kalimat tersebut, tetapi perilaku ini dapat dengan mudah berkembang menjadi bullying relasional dan meningkat menjadi bentuk yang lebih mengerikan, yaitu pengucilan sosial yang digunakan oleh anak-anak yang lebih besar. Misalnya, "Kamu tidak bisa menjadi teman saya jika kamu berteman dengan dia". Bahkan anak yang berusia lima tahun pun sudah ada yang mempunyai kemampuan dalam memanipulasi teman sekelas mereka untuk mem-bully teman sebayanya.

Pemahaman yang baik tentang berbagai cara bahwa anak-anak terlibat dalam berbagai bentuk bullying, pendidik anak usia dini dapat bersiap untuk mengatasi bullying melalui pencegahan, intervensi, dan tindak lanjut.

Bullying di kalangan anak-anak mungkin terlihat berbeda dari bullying di kalangan anak-anak remaja. Perilaku kekerasan atau agresif sebagai awal mula tindakan bullying akan terasa menyakitkan bagi korbanya dapat menyebabkan kekerasan ketika mereka lakukan secara berulang-ulang, disengaja dan melibatkan penyalahgunaan kekuasaan. Menghentikan bullying sesegera mungkin dapat mencegah perluasan dan penyebaran tindakan bullying secara nyata.

Tahapan kegiatan yang sudah dan sedang berlangsung adalah sebagai berikut:

1. Tahap I (Tahap Penyampaian Materi) Pada tahap ini akan dilakukan penyampaian materi yang meliputi:

a. Tingkat, keseriusan, dan dinamika dari bullying.

b. Bagaimana mengenali dan menanggapi lebih awal dan seefektif mungkin perilaku yang dapat menyebabkan bullying.

c. Strategi-strategi baru dan efektif tentang bagaimana mencegah bullying.

d. Bagaimana mempersiapkan anak-anak agar mengenali dan merespon secara efektif perilaku awal dari bullying.

e. Pengajaran kepada anak-anak bagaimana setiap orang (pembuli, korban bullying, dan saksi bullying, serta orang dewasa yang suportif) dapat membantu mencegah dan menghentikan bullying.

f. Penciptaan suatu lingkungan dimana setiap orang dapat memahami bahwa 
perilaku-perilaku bullying adalah tidak dapat diterima, merusak, akan tetapi juga dapat dicegah.

g. Pemberdayaan diri sendiri (guru dan staff PAUD) dan anak-anak untuk secara aktif memberikan intervensi untuk mencegah dan menghentikan bullying.

h. Antisipasi dan intervensi dampak bullying dari segi kesehatan anak.

i. Teknik penyusunan RPP tentang bullying yang bisa diterapkan selama proses belajar mengajar selama kurang lebih 30 menit, minimal sekali dalam seminggu dengan menggunakan materi poster, puppet role-play, story times, dan classroom rules.

Materi tersebut disampaikan dalam bentuk ceramah, tanya jawab, pelatihan, dan diakhiri dengan penugasan penyusunan RPP tentang bullying serta peer teaching sebagai simulasi dan sekaligus sebagai implementasi dari RPP tentang bullying yang telah di susun. Kegiatan ini akan dilaksanakan di kampus TK Mekar Jaya Semarang dan juga kampus PAUD Doa Ibu Semarang.

Tahap 1 sudah dilakukan dan sudah tuntas dengan minat peserta yang cukup antusias mengikuti pelatihan dan pengembangan pembelajaran anti-bullying berbasis sekolah bagi guru PAUD di Kota Semarang. Peserta pelatihan tidak hanya dari guru dan staff di lingkungan PAUD akan tetapi anggota komite sekolah juga ikut berpartisipasi dalam rangkaian acara pelatihan yang diadakan oleh tim pengabdi.

Hasil dari tahapan ini cukup memuaskan dimana para peserta sangat aktif dan interaktif dalam Tanya jawab dalam diskusi materi terkait dengan dinamika bullying, strategi stragtegi baru dan efektif pencegahan bullying, pembelajaran bertemakan bullying untuk anak usia dini, tips penciptaan lingkungan yang bebas dari kekerasan, tips pemberdayaan guru dan staff PAUD dalam pencegahan dan antisipasi bullying, solusi dampak kesehatan akibat efek dari bullying, serta kisi kisi pembelajaran dan penyusunan RPP bullying serta jadwalnya. Evaluasi solusion dan problem dalam bentuk quiz sangat interaktif dan menarik minat dan motivasi peserta untuk mendiskusikannya.

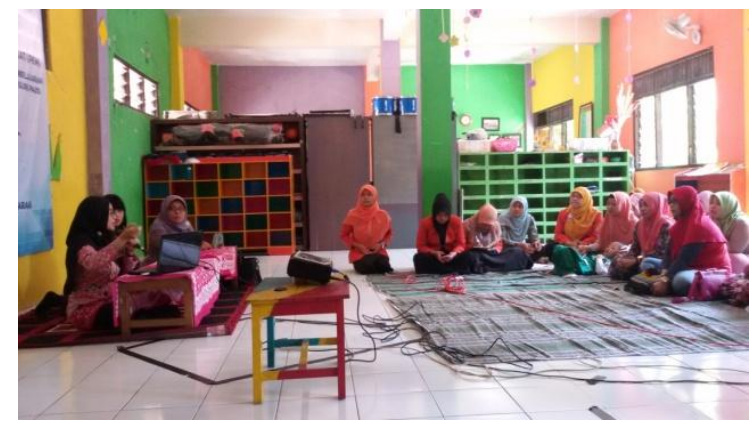

Gambar 1. Implementasi Tahap 1

Para peserta menjadi lebih memahami arti dari bullying bahwa Anakanak kecil menggertak dengan berbagai cara dan dengan berbagai macam tingkatan 
dalam dunia mereka yaitu anak usia dini.

Sebagian besar anak-anak yang menerima perlakuan bullying menggunakan agresi fisik langsung (misalnya, memukul, mendorong, mencubit, atau melempar benda) atau agresi verbal langsung (misalnya, berteriak, mengancam) untuk mengambil mainan, membuat seseorang melakukan sesuatu terhadap nya akan, atau hanya untuk melakukan bullying.

Selain itu, para peserta juga lebih memahami apa itu bullying dengan memaparkan berbagai macam contoh terkait dengan segala tindakakan yang berbau bullying. Seperti, anak anak yang suka melakukan bullying, mereka juga dapat menggunakan bentuk-bentuk yang lebih halus atau agresi fisik lagsung, seperti menyembunyikan mainan favorit, mengambil jaket seseorang, atau menghancurkan karya seni orang lain. Mereka mungkin menggunakan agresi relasional untuk mengabaikan anak dengan berbisik, menyebarkan desas-desus, atau mengatakan, "kamu tidak boleh bermain." Mereka mungkin mengisolasi target dengan melarikan diri dari dia dan mendorong orang lain untuk bergabung.

2. Tahap II (Tahap Pelatihan)

Tahap dua adalah tahap pelatihan. Dalam tahap ini peserta berlatih menyusun RPP tentang bullying sebagai tindak lanjut dari tahap pertama. Peserta pelatihan terdiri dari guru, staff, dan komite sekolah. Mereka cukup antusias menyusun RPP yang pada minggu berikutnya dapat dipraktekkan di kelas sebagai acuan untuk menerapkan program pembelajaran anti bullying di sekolah.

Pada tahap pelatihan ini, diharapkan guru dapat menghasilkan RPP tentang bullying yang kemudian untuk implementasi RPP tentang bullying tersebut dapat diterapkan dalam latihan peer teaching.

$$
\text { Hasil dari tahap pelatihan }
$$
penyusunan RPP adalah kemampuan guru PAUD membuat dan menyusun RPP berdasarkan materi dan bahan yang diberikan cukup memuaskan dan sudah cukup sesuai dengan template yang sudah disediakan oleh tim pengabdi. Standar kompetensi yang diharapkan, tujuan pembelajaran, indicator dan hasil yang diharapkan, serta skenario pembelajaran sudah cukup runtut dan jelas.

3. Tahap III ( Tahap Praktik Peer Teaching)

Setiap guru pada tahap ini melakukan praktek pembelajaran bullying dengan rekan mereka sendiri dalam bentuk peer teaching. Teknik pembimbingan dan pendampingan dilakukan untuk mengetahui tingkat pemahaman guru terhadap bagaimana penerapan RPP tentang bullying yang diterapkan dalam 
bentuk pembelajaran tentang bullying yang diintegrasikan dalam proses pengajaran di kelas melalui peer teaching.

Para peserta berlatih peer teaching seperti halnya yang tertera dalam lesson plan. Mereka mengajar peserta lain seolah olah seperti anak didik mereka sendiri. Dalam peer teaching, media pembelajaran yang dipakai adalah boneka tangan. Berikut ini adalah salah satu lesson plan yang dipraktekkan dalam tahap dua yaitu tahap pelatihan.

\section{Aktivitas Pembelajaran Anti Bullying}

\section{Bahan yang dibutuhkan:}

- Boneka

- $\quad$ Slip kertas (pilihan untuk adaptasi)

\section{Prosedur:}

1) Tujuan dari kegiatan ini adalah untuk memfasilitasi kegiatan diskusi dengan siswa terkait dengan segala macam perasaan yang timbul akibat bullying. Guru PAUD bisa menggunakan boneka barbie, atau boneka binatang. Kemudian memberikan nama kepada hewan tersebut seperti "Hendi" atau "Rusli." Tampilkan boneka tersebut didepan kelas dan perkenalkan mereka.

2) Katakan didepan siswa kelas tentang "beberapa hal yang telah terjadi terhadap boneka boneka tersebut, misalnya apa yang terjadi terhadap "Hendi" di sekolah. Guru PAUD akan meminta anak anak untuk membantu memahami hal hal apakah yang bisa membuat Hendi merasa sakit hati. "

3) Beritahu anak anak tentang setiap hal yang bisa membuat kita merasa tidak nyaman atau sakit hati. Selanjutnya guru bisa meminta siswa "Apa saja yang bisa membuat Hendi merasa sakit hati?"

$\checkmark$ Seseorang mengatakan kepada Hendi "Kau bukan temanku."

$\checkmark$ Seseorang mengatakan kepada Hendi "Kamu tidak bisa bermain bola" ketika Hendi sedang bermain bola.

$\checkmark$ Seseorang memukul Hendi dengan sengaja.

$\checkmark$ Seseorang menyebut Hendi dengan sebutan "bodoh" dan mengatakan bahwa tidak ada seorang anak pun yang menyukainya.

$\checkmark$ Seseorang mengambil kue milik Hendi saat makan siang dan tidak memberikannya kembali.

4) Katakan kepada anak anak bahwa hal hal tersebut diatas adalah contoh bullying dan mengingatkan kepada mereka bahwa bullying adalah ketika seseorang melakukan sesuatu dengan tujuan untuk membuat seseorang merasa sakit hati atau tidak nyaman 
dan sangat sulit untik membuat anak tersebut berhenti menyakiti.

5) Katakan kepada anak anak bahwa "tidak baik membentak atau menggertak karena gertakan atau bentakan akan membuat seseorang merasa tidak nyaman atau tersakiti."

6) Akhiri sesi dengan aksi anti bullying bersama sama dengan anak anak.

\section{Skenario}

$\checkmark$ Memukul seseorang karena suatu alasan

$\checkmark \quad$ Menendang seseorang karena sebuah alasan

$\checkmark$ Melempar barang ke seseorang dengan tujuan untuk menyakiti mereka.

$\checkmark$ Memanggil nama dengan sebutan yang menyakitkan hati

$\checkmark$ Menggoda seseorang teman yang mengenakan kacamata atau kawat gigi

Hasil dari Praktek ini 100\% peserta yaitu Guru TK PAUD Doa Ibu Semarang dan TK Mekar Jaya Semarang bisa mempraktekan pembelajaran bullying dengan mengembangkan RPP dari tim pengabdi sesuai dengan kondisi dan situasi yang dibutuhkan di lingkungan sekolah mereka. Meskipun, kemampuan dalam praktek mengajar berbeda antara satu guru dan yang lainnya. Terutama guru senior, sudah punya pengalaman banyak bagaimana menghadapi anak usia dini yang agresif lebih kreatif bagaimana menghadapi bullying berdasarkan simulasi masalah yang sudah disediakan dalam bentuk RPP oleh tim pengabdi. Guru yang kurang berpengalaman dan masih baru, masih meminta pencerahan dan contoh contoh solusi dari guru senior maupun dari tim pengabdi.

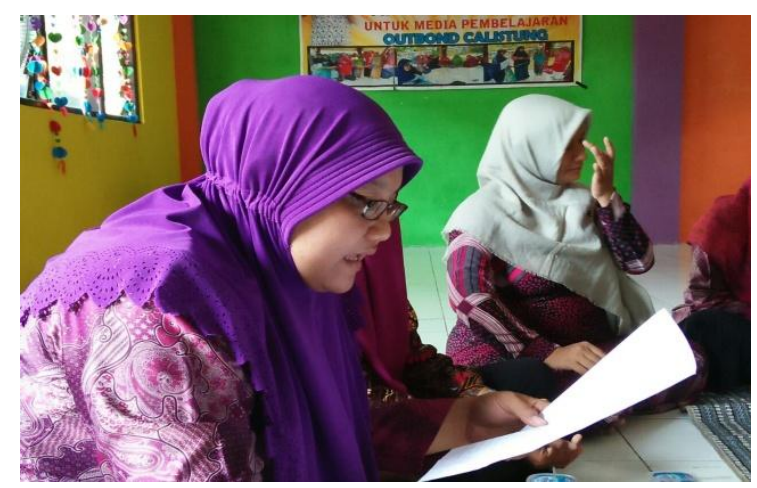

Gambar 2. Implementasi Tahap 3

\section{Tahap IV (Tahap Praktik Classroom Practice)}

Tahapan pelatihan dan pengembangan pembelajaran anti-bullying berbasis sekolah di PAUD Kota Semarang selanjutnya adalah tahap ke empat yaitu tahap praktik di kelas dimana lesson plan di terapkan di kelas dan yang bermain peran dalam tema bullying adalah anak anak usia dini. Dengan menggunakan salah satu metode pembelajaran yaitu bermain peran, maka anak usia dini akan berlatih memerankan sebagai pembully, korban bullying, dan sebagai pengamat. Anak usia dini akan berlatih memahami bagaimana perasaan yang dialami korban bullying. 
Dan mereka juga akan belajar bermain peran sebagai pembully dan pengamat serta mendiskusikan sisi baik dan sisi negatif dari berbagai permasalah bullying.

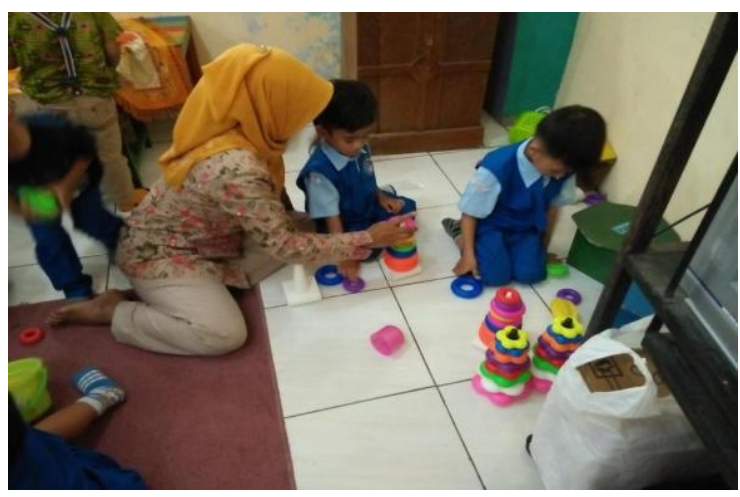

Gambar 3. Implementasi Tahap 4

Setiap guru pada tahap ini melakukan praktek pembelajaran bullying di kelas mereka masing-masing. Teknik pembimbingan dan pendampingan dilakukan untuk mengetahui tingkat pemahaman guru terhadap bagaimana penerapan RPP tentang bullying yang diterapkan dalam bentuk pembelajaran tentang bullying yang diintegrasikan dalam proses pengajaran di sekolah mereka sendiri, yakni dalam bentuk:

a) Tim pelaksana pengabdian pada masyarakat melakukan pemantauan dan evaluasi ke sekolah-sekolah tempat praktik guru menerapkan pembelajaran tentang bullying,

b) Melakukan bimbingan dan pendampingan di luar sekolah seperti melalui telepon dan e-mail,

c) Guru dapat melakukan konsultasi dengan tim pelaksana (instruktur) di kampus Universitas PGRI Semarang jika diperlukan.

Hasil pelatihan pada tahap IV ini adalah penerapan RPP yang disediakan oleh tim pengabdi diterapkan di kelas-kelas guru TK di masing masing sekolah mereka dengan cukup memuaskan. Para guru cukup kreatif bagaimana mengangkat tema bullying dalam topic pembelajaran dengan menggunakan puppet ataupun dengan tehnik role-playing. Selain itu, pembelajaran dengan tema bullying mengembangkan ketrampilan social anak untuk lebih peduli dan menyayangin orang lain, terutama teman mereka sendiri.

\section{Tahap V ( Tahap Diskusi \& Refleksi Diri)}

Tahap terakhir dari program pelatihan dan pengembangan pembelajaran anti-bullying berbasis sekolah adalah tahap diskusi dan refleksi diri sekaligus sharing dari masing-masing guru tentang kelebihan dan juga kekurangan terhadap pembelajaran bullying sebagai bagian dari pelatihan dan pengembangan pembelajaran anti-bullying yang diterapkan di sekolah mereka. Bimbingan dan pendampingan pada tahap ini dilakukan di kampus TK Mekar Jaya Semarang dan juga kampus PAUD Doa Ibu Semarang. Dalam tahap ini adalah tahap diskusi keberhasilan dan 
permasalahan selama praktek penerapan pembelajaran anti bullying di kelas.

Hasil dari tahap ini adalah para guru PAUD saling diskusi dan refleksi diri sekaligus sharing dari masing-masing guru tentang kelebihan dan juga kekurangan terhadap pembelajaran bullying sebagai bagian dari pelatihan dan pengembangan pembelajaran anti-bullying yang diterapkan di sekolah mereka. Hasil dari diskusi dan sharing tentang permasalahn dan solusi yang diambil terkait tema tema tentang intervensi anti bullying menjadikan ide bagi guru guru lain untuk lebih mengembangkan strategi strategi intervensi anti bullying baik di dalam maupun di luar kelas. Bimbingan dan pendampingan pada tahap ini dilakukan di kampus TK Mekar Jaya Semarang dan juga kampus PAUD Doa Ibu Semarang.

\section{SIMPULAN}

Program pengabdian masyarakat bertema pelatihan dan pengembangan pembelajaran anti-bullying berbasis sekolah bagi guru PAUD di Kota Semarang diharapkan dapat memaksimalkan warga sekolah dalam hal ini di lingkungan PAUD akan lebih meningkatkan pengawasan bullying pada anak usia dini karena jika bullying tidak dihentikan maka perilaku bullying akan berkembang dan menyebar. Materi pelatihan dan pengembangan program disampaikan dalam bentuk ceramah, tanya jawab, pelatihan, dan diakhiri dengan penugasan penyusunan RPP tentang bullying serta peer teaching sebagai simulasi dan sekaligus sebagai implementasi dari RPP tentang bullying yang telah di susun. Kegiatan ini akan dilaksanakan di kampus TK Mekar Jaya Semarang dan juga kampus PAUD Doa Ibu Semarang.

Tahap 1 sudah dilakukan dan sudah tuntas dengan minat peserta yang cukup antusias mengikuti pelatihan dan pengembangan pembelajaran anti-bullying berbasis sekolah bagi guru PAUD di Kota Semarang Hasil dari tahapan ini cukup memuaskan dimana para peserta sangat aktif dan interaktif dalam Tanya jawab dalam diskusi materi terkait dengan dinamika bullying, strategi stragtegi baru dan efektif pencegahan bullying, pembelajaran bertemakan bullying untuk anak usia dini, tips penciptaan lingkungan yang bebas dari kekerasan, tips pemberdayaan guru dan staff PAUD dalam pencegahan dan antisipasi bullying, solusi dampak kesehatan akibat efek dari bullying, serta kisi kisi pembelajaran dan penyusunan RPP bullying serta jadwalnya.

Selanjutnya pada tahap dua adalah tahap pelatihan menyusun RPP tentang bullying 
sebagai tindak lanjut dari tahap pertama. Hasil dari tahap pelatihan penyusunan RPP adalah kemampuan guru PAUD membuat dan menyusun RPP berdasarkan materi dan bahan yang diberikan cukup memuaskan dimana standar kompetensi yang diharapkan, tujuan pembelajaran, indicator dan hasil yang diharapkan, serta skenario pembelajaran sudah cukup runtut dan jelas.

Pada tahap III, para peserta berlatih peer teaching mengajar peserta lain seolah olah seperti anak didik mereka sendiri. Dalam peer teaching, media pembelajaran yang dipakai adalah boneka tangan. Hasil dari Praktek ini $100 \%$ peserta yaitu Guru TK PAUD Doa Ibu Semarang dan TK Mekar Jaya Semarang bisa mempraktekan pembelajaran bullying dengan mengembangkan RPP dari tim pengabdi sesuai dengan kondisi dan situasi yang dibutuhkan di lingkungan sekolah mereka.

Tahapan selanjutnya adalah tahap ke empat yaitu tahap praktik di kelas dimana lesson plan di terapkan di kelas dan yang bermain peran dalam tema bullying adalah anak anak usia dini. Hasil pelatihan pada tahap IV ini adalah para guru cukup kreatif bagaimana mengangkat tema bullying dalam topic pembelajaran dengan menggunakan puppet ataupun dengan tehnik role-playing di kelas mereka.
Tahap terakhir dari program pelatihan dan pengembangan pembelajaran antibullying berbasis sekolah adalah tahap diskusi dan refleksi diri sekaligus sharing dari masing-masing guru tentang kelebihan dan juga kekurangan terhadap pembelajaran bullying. Hasil dari tahap terakhir ini adalah diskusi dan sharing tentang permasalahn dan solusi yang diambil terkait tema tema tentang intervensi anti bullying menjadikan ide bagi guru guru lain untuk lebih mengembangkan strategi strategi intervensi anti bullying baik di dalam maupun di luar kelas.

Mitra berkomitmen untuk mengembangkan RPP Anti Bullying dan menerapkannya dalam proses pembelajaran bersama siswa-siswi PAUD

\section{SARAN}

Program bullying ini bukan pekerjaan kepala sekolah secara tunggal, akan tetapi ini adalah karya kolaboratif dari semua elemen sekolah yang terintegrasi dengan proses pembelajaran di kelas yang secara bersama sama dan terintegrasi dengan kurikulum dan juga orang tua sebagai lingkungan keluarga yang paling kecil. Oleh karena itu, program penanganan bullying berbasis sekolah adalah salah satu upaya untuk menciptakan lingkungan yang bebas dari kekerasan. Pencegahan dan antisipasi bullying sejak 
dini akan menciptakan generasi bangsa yang mempunyai ketrampilan sosial yang memadai untuk mampu terjun dalam dunia masyarakat dengan memberikan sumbangsih yang tidak hanya berguna bagi diri sendiri tetapi juga keluarga, masyarakat, dan bangsa.

Bullying tidak akan hilang begitu saja kalau kita tidak mengusahakannya, salah satu usaha yang bisa ditempuh di lingkungan sekolah adalah menyelipkan program pembelajaran anti bullying berbasis sekolah selama seminggu sekali dengan durasi kurang lebih 30 menit sehingga anak usia dini dan kita selaku orang dewasa baik sebagai guru maupun staff akan selalu waspada terhadap segala bentuk tindakan kekerasan di lingkungan sekolah yang mengarah pada aksi bullying.

\section{UCAPAN TERIMA KASIH}

Terima kasih kepada Kemenristek Dikti yang telah mendanai kegiatan $\mathrm{I}_{\mathrm{b}} \mathrm{m}$ Pelatihan dan Pengembangan Pembelajaran Anti-Bullying Berbasis Sekolah Bagi Guru Paud Kota Semarang. Terima kasih kami ucapkan pula untuk LPPM Universitas PGRI Semarang atas segala fasilitas yang diberikan.

\section{DAFTAR PUSTAKA}

Ahmed, E., \& Braithwaite, V. (2006). Forgiveness, reconciliation, and shame: Three key variables in reducing school bullying. Journal of Social Issues, 62(2), 347-370.

Bollmer, J. M., Harris, M. J., \& Milich, R. (2006). Reactions to bullying and peer victimization: Narratives, physiological arousal, and personality. Journal of Research in Personality, 40, 803-828.

Efianingrum, Ariefa. 2009. Mengurai Akar Kekerasan (Bullying) di Sekolah. Jurnal Dinamika 2009.

Jolliffe, D., \& Farrington, D. P. (2006). Examining the relationship between low empathy and bullying. Aggressive Behavior, 32, 540-550.

Sumiarni, Endang, M. G. 2009. Kekerasan di Sekolah dan Hak Anak dalam Perspektif Hukum. Makalah Seminar "Fenomena Kekerasan di Sekolah dan Strategi Pencegahannya", 2 Agustus 2009, FIP UNY.

Nansel, T. R., Overpeck, M., Pilla, R. S., Ruan, W., Simons-Morton, B., \& Scheidt,P. (2001). Bullying behaviors among US youth: Prevalence and association with psychosocial adjustment. Jama: Journal of the American Medical Association, 285, 2094-2100.

Olweus, D., Limber, S., \& Mihalic, S. (1999). The bullying prevention program: Blueprints for violence prevention. Boulder, CO: Center for the Study and Prevention of Violence. Retrieved October 24, 2014, from http://www.colorado.edu/cspv/safes chools/bullying/bullying_bppsumm ary.html 
Orpinas, P., \& Horne, A. M. (2005). Bullying prevention: Creating a positive school climate and developing social competence. Washington, DC: American Psychological Association.

Phillips, D. A. (2007). Punking and bullying: Strategies in middle school, high school, and beyond. Journal of Interpersonal Violence, 22(2), 158-178.

Rigby, K. (2003). Consequences of bullying in schools. Canadian Journal of Psychiatry - Revue Canadienne de Psychiatrie, 48, 583-590.

Rios-Ellis, B., Bellamy, L., \& Shoji, J. (2000). An examination of specific types of ijime within Japanese schools. School Psychology International, 21, 227-241.

Sharp, S., \& Smith, P. (1994). Tackling bullying in your school: A practical handbook for teachers. London: Routledge.

Suneki, Sri., Ambarini, Ririn., dan Destriani, Dwi. 2012. "Peningkatan Character Building dan Kreativitas Anak Usia Dini Melalui TPR Warm Up Game Pada Anak Didik Kelompok A TK Doa Ibu Kecamatan Tembalang Semarang". Semarang: LPPM IKIP PGRI Semarang. (tidak diterbitkan).

Suneki, Sri., Wardoyo, L. Subur., dan Ambarini, Ririn. 2013. Pengembangan Perangkat Pembelajaran Anak Usia dini melalui Game Edukasi Fairy Tales Berbasis Pendidikan Moral. Semarang: LPPM IKIP PGRI Semarang. (tidak diterbitkan).
Taub, J. (2001). Evaluation of the Second Step Violence Prevention Program at a rural elementary school. School Psychology Review, 31, 186-200.

Undang-Undang Republik Indonesia Nomor 23 Tahun 2002 Tentang Perlindungan Anak

Vaillancourt, T., Hymel, S., \& McDougall, P. (2003). Bullying is power: Implications for school-based intervention strategies. Journal of Applied School Psychology, 19(2), 157-176.

Wardoyo, Laksmono, S., Ambarini, Ririn., dan Destriani, Dwi. 2012. Peningkatan Role Playing dalam Pembelajaran Bahasa Inggris Berbasis Beyond Center and Circle Time (BBCT) pada Anak Didik PAUD Al Azam Semarang. Semarang: LPPM IKIP PGRI Semarang. (tidak diterbitkan). 